\title{
Error Analysis of Problem Posed by Pre-service Primary Teachers based on Semantic Structures
}

\author{
Lydia Lia Prayitno \\ Universitas PGRI Adi Buana \\ Surabaya, Indonesia \\ lydia.liaprayitno5@gmail.com
}

\author{
Sunu Catur Budiyono \\ Universitas PGRI Adi Buana \\ Surabaya, Indonesia \\ sunucatur85@gmail.com
}

\begin{abstract}
Goal this study to error analyze problems posed by pre-service primary teachers about addition operation fraction based on semantic structures. 46 pre-service primary teachers participated in this study and in their seventh semester of preservice primary teachers department have finished experience program. Pre-service teachers have requested problems posing about addition fraction which is given. Each problems must be related to a daily situation based given operation. Data obtained were classified to the semantic structure in part-part-whole relations and joining action problems. Next, problems were analyzed to types of errors conducted by pre-service teachers. Result in this study, most pre-service primary teachers made errors in problems they posed that (1) not related to the daily situation, (2) out of context about fraction concept, and (3) unit given are not suitable to the daily situation.
\end{abstract}

Keywords—analysis, problem posed, fraction, semantics

\section{I.INTRODUCTION}

Many studies about problem posing was done by researchers i.e. Silver, et al. (1996); Rahman (2009); Isik\& Kar (2012); Isik\& Kar (2014); etc. Problem posing has a strategic position in learning mathematics, because problem posing effective for building critical thinking [10]. To teach critical thinking to their students, the teacher should also think critically too. So, this can be done through problem posing. This is important for teacher especially for a pre-service teacher that will teach at the school.

Problem posing asks new problems based a given situation before solving it [11]. Silver [12] proposed posing problem applied to three different forms of mathematical cognitive activity, that is (1) presolution posing, student produces a problem from a given situation or stimulus or given; (2) withinsolution posing, a student re-formulating the problem as it is being resolved; and (3) post solutions posing, student modifies an objective or problem condition that has been solved to generate a new problem.In this study, produce problems or question based on the situation are given by researcher $[12$, 13].

Problem posing relates to the complexity and quality of the mathematical problems posed. New problems are made involves formulation from given situation and based experience subject [NCTM, 2000]. Silver [12] classifies problem solving questions into 3 types:

- Mathematics questions, questions that contain mathematical problems and related to the information provided (i.e pose a problem that could solve operation $\frac{1}{2}+\frac{3}{4}$ ). Furthermore, math questions can be classified on mathematical questions that can be solved and math questions can't be solved.

- non-math questions, questions that don't contain math problems.

- statement, the response only a conjecture and doesn't contain sentences of questions or commands guided to mathematics or non-mathematics.

Mathematical questions that can be solved given attention syntax and semantics. The syntax is related to grammar, and semantics is related to the meaning of word or sentence. Carpenter [1996] has four categories of addition and subtraction problems can be identified problems involving (a) joining the action, (b) separating action, (c) part-part-whole relations, and (d) comparison situations.

In this study, we interested problem posing about fraction and given attention to semantic structure based on two classes, that is joining the action and part-part-whole relation. Problems in the joint category involve a process as the first amount, the change, and the resulting amount. Problems in the part-partwhole category consist of the combination of two different parts that could be transformed into a whole [15]. Classification problem posed by students can be draw.

Studies indicate that pre-service teachers have difficulties posing problems on operations with fractions $[6,7,8]$. Kiliç [7] investigated the types of meanings fractions, which pre-service primary teachers in problems they posed about fraction operations. It was found that operational meaning of dividing and subtracting fractions is preferred. Kar \& Isik [6] investigated problem posed by pre-service mathematics teacher about fraction based semantic structure. It was found eight types of errors are determined based on the problem posed by the pre-service teacher. McAllister \& Beaver [8] expressed errors in problems on fractions posed by pre-service primary teachers in the form not being able to pose problems with daily life situations, not being able to write fraction numbers in 
accurate units, posing illogical problems, and attributing the natural number meaning to fractions. In this study, would errors analysis classroom pre-service primary teacher to the posed problem about addition fraction.

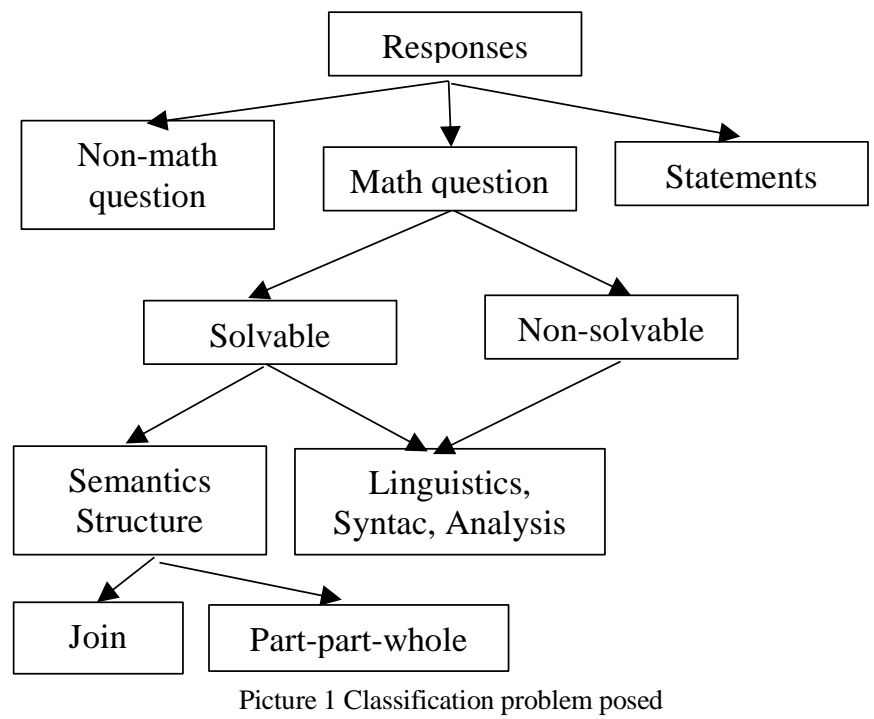

Fraction is one important subject to learn in school because many it contain benefits in daily life. Example recipe cake use fraction (ie. $1 / 3$ cup sugar, $1 / 2$ gr salt, etc) and help to measure out the required quantities [4]. In Indonesia, based on 2013 curriculum, fraction taught begin $4^{\text {th }}$ class elementary school in theme "Caring for Living Beings" and subtheme "Diversity Living Being in My Territory". Before teaching about fraction, the teacher must have much information related fraction, experience in daily life situation to make understanding students about fraction. This can be realized by rich learning environment to make concrete fraction concept. The teacher must have skills to related daily life situation about fraction and written symbols. Based on different meanings can show different problem structures and this problem can be used as an evaluation tool, analyzing the contextual structure of the proposed problem about the meaning associated with the operation of additional fraction [6]. The goal this study to analyze errors problem posed by pre-service classroom primary teacher based semantic structure.

\section{II.METHOD}

Pre-service teachers participated in this study and the seventh semester in pre-service primary teacher department. Pre-service teachers have finished experience program at class, microteaching, and at the elementary school. All of the participants have passed subject basic concept mathematics, teaching and learning mathematics.

Data collection in this study worksheet problem posing about fraction that consists two operations. This worksheet was adapted from Kar \& Isik [6] that is to use operation proper fractions. The pre-service teacher asked to pose one problem related in a daily life situation that can be solved using operation is given. Characterization situation in this study can give by table 1 .

TABLE I. CHARACTERIZATION PROBLEM

\begin{tabular}{cl} 
Operation & \multicolumn{1}{c}{ Characterization } \\
\hline$\frac{1}{2}+\frac{1}{3}$ & $\begin{array}{l}\text { Addition two proper fractions and result proper } \\
\text { fraction }\end{array}$ \\
\hline$\frac{1}{2}+\frac{3}{4}$ & $\begin{array}{l}\text { Addition two proper fractions and result mixed } \\
\text { fraction }\end{array}$ \\
\hline
\end{tabular}

Responses from pre-service teachers were analyzed in three steps. First step, grouping responses through math question and non-math question. Math question are problem posed by preservice teacher can be solved use operation is given. While non-math question are problem posed by pre-service teacher that can't be solved use operation is given. The second step, grouping math question based on semantics structure, joint category, part-part-whole category, and not both. In this step, each category can be a percentage from math question. The last step, determine errors type from problem posed by pre-service teachers. Data were analyzed based context analysis according to context daily life situation and describe errors that preservice teachers doing. Each category type can be a percentage from errors type. Not close the possibility in one problem posed by pre-service teachers contain two and more type errors. Process to analyze data is illustrated below

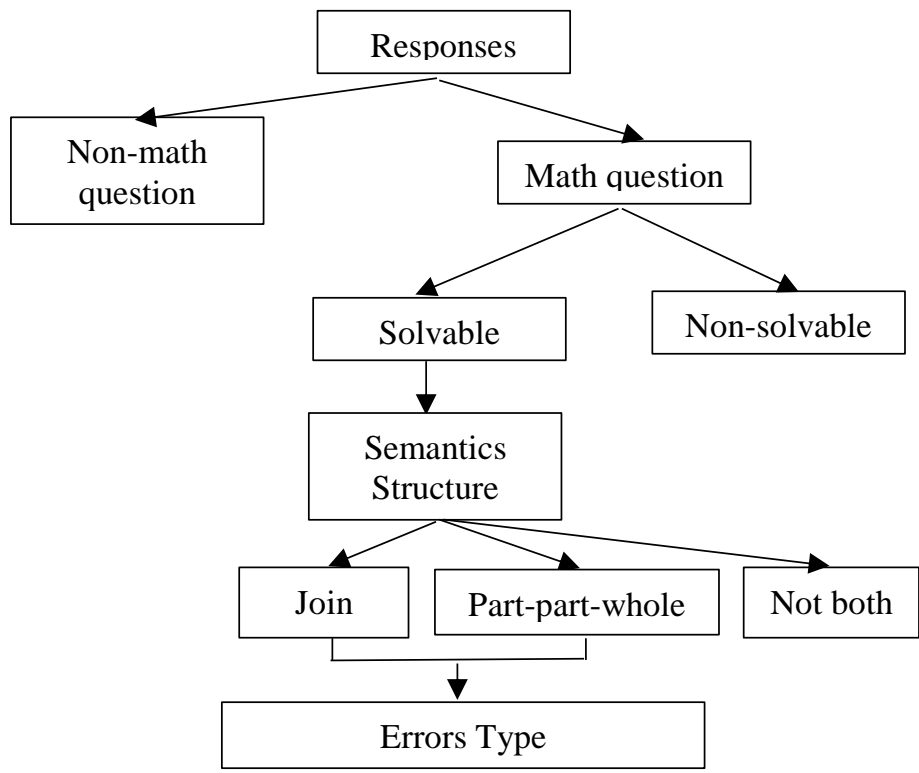

Picture 2 Data Analysis

\section{III.RESULT AND DISCUSSION}

Pre-services teachers asked problem posing about additional fraction about 30 minutes. The purpose is preservice teaches sure about the problem posed, then responses were analyzed by the semantic structure. First steps, grouping distribution responses given by 46 pre-services teacher item based on math question and non-math question given in table II. 
TABLE II. DISTRIBUTION RESPONSES PRE-SERVICES TEACHER BASED ON MATH QUESTION AND NON-MATH QUESTION

Operation Math question $\quad$ Non-math question

\begin{tabular}{ccc} 
Operation & Math question & Non-math question \\
\hline$\frac{1}{2}+\frac{1}{3}$ & 43 & 3 \\
$\frac{1}{2}+\frac{3}{4}$ & $93.48 \%$ & $6.52 \%$ \\
\hline
\end{tabular}

Based table II, for the operation I problem posed by a preservice teacher in math question is 43 subject or $93.48 \%$, and the non-math question is 3 subject or $6.52 \%$. For operation II problem posed by a pre-service teacher in math question is 44 subject or $95.65 \%$ and the non-math question is 2 subject $(4.35 \%)$. Next step, the problem posed in non-math question no longer used.

The second step, grouping math question based on semantics structure. Grouping distribution responses 46 preservices teachers based joint category, part-part-whole category, and not both given by table III.

TABLE III. DISTRIBUTION RESPONSES PRE-SERVICES TEACHER BASED ON JOINT AND PART-PART-WHOLE CATEGORY

\begin{tabular}{cccc} 
Operation & Joint & Part-part-whole & Not both \\
\hline$\frac{1}{2}+\frac{1}{3}$ & 28 & 11 & 4 \\
$\frac{1}{2}+\frac{3}{4}$ & $65.12 \%$ & $25.58 \%$ & $9.3 \%$ \\
\hline & 34 & 9 & 1 \\
\hline
\end{tabular}

Based table III, for the operation I problem posed by the pre-service teacher based on joint category is 28 subject or $65.12 \%$, the part-part-whole relation is 11 subject or $25.58 \%$, and not both is 4 subject $(9.3 \%)$. While for operation II problem posed by the pre-service teacher based on joint category is 34 subject $(77.27 \%)$, the part-part-whole relation is 9 subject or $20.45 \%$, and not both is 1 subject or $2.23 \%$.

The third step, determine errors type from problem posed by pre-service teachers. Data were analyzed based context analysis according to context daily life situation and describe errors that pre-service teachers doing. Describe errors type can be analyzed for each operation. For operation I given by table IV.

TABLE IV. ERRORS TYPE OPERATION I

\begin{tabular}{|c|c|c|}
\hline Operation & $\begin{array}{c}\text { TABLE IV. } \begin{array}{l}\text { ERRORS TYPE OPERATIO } \\
\text { Errors Type }\end{array} \\
\end{array}$ & Percentage \\
\hline \multirow{4}{*}{$\frac{1}{2}+\frac{1}{3}$} & $\begin{array}{l}\text { - Operation problem posed not related in } \\
\text { daily life situation }\end{array}$ & $\begin{array}{c}29 \\
72.25 \% \\
\end{array}$ \\
\hline & $\begin{array}{l}\text { - Unit is given not related in daily life } \\
\text { situation }\end{array}$ & $\begin{array}{c}1 \\
2.5 \% \\
\end{array}$ \\
\hline & $\begin{array}{l}\text { - The question does not match the given } \\
\text { operation }\end{array}$ & $\begin{array}{c}9 \\
22.5 \% \\
\end{array}$ \\
\hline & $\begin{array}{l}\text { - Give value to the whole fraction } \\
\text { concept }\end{array}$ & $\begin{array}{c}1 \\
2.5 \%\end{array}$ \\
\hline
\end{tabular}

In table IV, errors type operation problem posed not related in daily life situation: failure expressing verbally not related in a daily situation. The problem posed by $\mathrm{S} 1$ as follows: You have a red ribbon. Each band has a length of $\frac{1}{3} \mathrm{~cm}$ and also has 3 pieces of white ribbon. Each ribbon has a length of $\frac{1}{2}$. The length of your ribbon now? In the problem, not related to daily life situation because there is no length $\frac{1}{3} \mathrm{~cm}$ and there is no length $\frac{1}{2}$ without clear units. From problem posed by S1, we know that unit that given not related in daily life situation and unit written not accordance the other units.

Type errors question does not match the given operation: subject does not root question accordance situation given and gives value to the whole fraction. The problem posed by S31 as follows: My Daddy has 30 marbles. $\frac{1}{3}$ given to Dino and $\frac{1}{2}$ again given to Fira. What is the amount of residual Daddy have now?. The problem that posed by the pre-service teacher, not related operation is given, because asked residual from marbles Daddy have. Besides that, this problem given value to the whole fraction concept that is My Daddy has 30 marbles. That is contrary to given operation and concept fraction.

Errors type for operation II given by table V.

\begin{tabular}{|c|c|c|}
\hline Operation & $\begin{array}{cc}\text { TABLE V. } & \begin{array}{l}\text { ERRORS TYPE OPERATION } \\
\text { Errors Type }\end{array} \\
\end{array}$ & Percentage \\
\hline \multirow{5}{*}{$\frac{1}{2}+\frac{3}{4}$} & $\begin{array}{l}\text { - Operation problem posed not related in } \\
\text { daily life situation }\end{array}$ & $\begin{array}{c}18 \\
40.91 \% \\
\end{array}$ \\
\hline & - Unit not related in daily life situation & $\begin{array}{c}11 \\
25 \%\end{array}$ \\
\hline & $\begin{array}{l}\text { - The question does not match the given } \\
\text { operation }\end{array}$ & $\begin{array}{c}7 \\
15.91 \% \\
\end{array}$ \\
\hline & $\begin{array}{l}\text { - Give value to the whole fraction } \\
\text { concept }\end{array}$ & $\begin{array}{c}2 \\
4.54 \% \\
\end{array}$ \\
\hline & $\begin{array}{l}\text { - Failure establishing relation fraction } \\
\text { concept }\end{array}$ & $\begin{array}{c}7 \\
15.91 \%\end{array}$ \\
\hline
\end{tabular}

In table $\mathrm{V}$, errors type operation problem posed not related in daily life situation: failure expressing verbally not related in a daily situation. The problem posed by S37 as follows: Brian's have a garden park and fish pool. The park has an area of $\frac{1}{2} m$ and $\frac{3}{4} m$ used for fish pools. How wide is Mr Brian's home page?. In the problem, not related to daily life situation because there is no area park $\frac{1}{2}$ meter and fish pool's area are a $\frac{3}{4}$ meter. Unit in this problem not related daily life situation, because unit area are square meters.

For errors type question does not match the given operation showed by S41. The problem posed by S41 as follows: Aunty took $\frac{2}{4} \mathrm{~kg}$ of chili in the garden. The next day Aunty harvested 
more $\frac{3}{4} \mathrm{~kg}$ of chili. How many chilies are harvested?. The answer for this question does not match the given operation.

For errors given value to the whole fraction is given by S28. The problem posed by S28 as follows:Debi has 1 liter of perfume and Aini has 2 liters of perfume. Dimas is their friend, while Dimas asks $\frac{1}{2}$ liters of perfume belongs to Debi and $\frac{3}{4}$ belongs to Aini. Now how many liters of Dimas have perfume? Two pre-service teachers give attributed numeric values to the whole and expressed that the fraction numbers were a certain amount of these numerical values. For failure establishing relation fraction concept given by S26. The problem posed by S26 as follows:Syfa ate soup $\frac{1}{2}$ part in a bowl. While Ani ate soup $\frac{3}{4}$ part in a bowl Syfa. What is the total soup that Syfa and Ani eaten?. This type of error contains responses that their addition is bigger than the whole. Therefore, she cannot eaten of her bowl because the result bigger than whole. Therefore, the problem statement is not meaningful in terms of part-whole relation.

Five types errors in this study that is (1) operation problem posed not related in daily life situation; (2) unit is given by preservice teachers not related in daily life situation; (3) the question does not match the given operation; (4) give value to the whole fraction concept; and (5) failure establishing relation fraction concept. The most frequent errors problem posed by pre-service teacher not related in daily activities, unit is given, give value to the whole fraction, and failure establishing relation. This based on McAllister \& Beaver [8] on analyzing errors of pre-service primary teachers in the problems posed on fraction operations. This is caused understanding pre-service teacher about fraction is weak.

\section{IV.CONCLUSION}

This study concluded that problem-posing performances of pre-service teachers with fractions were rather low. Problemposing performances of pre-service teachers, who used two different semantic structures, were found to be better than those, who posed in monotype that is joint or part-part-whole structures. This result indicates the importance of including problem posing activities with different semantic structures in teacher programs.

\section{REFERENCES}

[1] Akay, H. \& Boz, N. (2008). The Effect of Problem Posing Oriented Calculus-II Instruction On Academic Success. https://www.researchgate.net/publication/263627772_The_Effect_of_Pr oblem_Posing_Oriented_Calculus-

II Instruction on Academic Success

[2] Christou, C., Mousoulides, N., Pittalis, M., Pantazi, D. M., Sriraman, B (2005). An Empirical Taxonomy of Problem Posing Processes. Zentralblatt für Didaktik der Mathematik (ZDM) - The International Journal on Mathematics Education Vol. 37(3).

[3] Carpenter, T. P., Fennema, E., \& Franke, M. L. (1996). Cognitively guided instruction: A knowledge base for reform in primary mathematics instruction. The Elementary School Journal, 97(1), 3-20.

[4] Hannich, L. (2009). Why are Fractions so Important?. International Learning Coorporation.

[5] Isik, C. \& Kar, T. (2012). An Error Analysis in Division Problems in Fractions Posed by Pre-Service Elementary Mathematics Teachers. Educational Sciences:Theory \& Practice - 12(3), 2303-2309.

[6] Kar, T. \& Isik, C. (2014). Analysis of Problems Posed by Pre-service Primary Teachers about Adding Fractions in terms of Semantic Structures. International Society of Education Research 9(2), 135-146.

[7] Kiliç, Ç. (2013). Pre-service primary teachers' free problem-posing performances in the context of fractions: An example from Turkey. The Asia-Pacific Education Researcher, 1-10.

[8] McAllister, C. J., \& Beaver, C. (2012). Identification of error types in preservice teachers' attempts to create fraction story problems for specified operations. School Science and Mathematics 112(2), 88-98.

[9] National Council of Teachers of Mathematics (NCTM). (2000). Principles and Standard forschool mathematics. Reston, VA: National Council of Teachers of Mathematics.

[10] Rahman, A. (2009). Profil Pengajuan Masalah Matematika Berdasarkan Gaya Kognitif Siswa. Universitas Negeri Surabaya. Disertasi yang Tidak Dipublikasikan Schleppegrell, M. J. \& Bowman, B. 1995. Problem Posing:A Tool for Curriculum Renewal. ELT Journal Volume 49

[11] Schleppegrell, M. J. \& Bowman, B. 1995. Problem Posing:A Tool for Curriculum Renewal. ELT Journal Volume 49

[12] Silver, E. A. (1994). On mathematical problem posing. For the Learning of Mathematics, 14(1),19-28.

[13] Silver, E. A., \& Cai, J. (1996). An analysis of arithmetic problem posing by middle school students. Journal for Research in Mathematics Education, 27, 521-53.

[14] Siswono, T. Y. E. (1999). Metode Pemberian Tugas Pengajuan Soal (Problem Posing) dalam Pembelajaran Matematika Pokok Bahasan Perbandingan di MTs Negeri Rungkut Surabaya. Tesis. PPs Unesa Surabaya

[15] Siswono, TYE. (2007). Penjenjangan Kemampuan Berpikir Kreatif dan Identifikasi Tahap Berpikir Kreatif Siswa dalam Memecahkan dan Mengajukan Masalah Matematika. Universitas Negeri Surabaya. Disertasi yang Tidak Dipublikasikan.

[16] Walle, J. A. (2004). Elementary and midddle school mathematics (fifth edition). Virginia Commonwealth University press. 